\title{
Late Cretaceous gastropod egg capsules from the Netherlands preserved by bioimmuration
}

\author{
Michał Zatoń, Paul D. Taylor, and John W.M. Jagt \\ Acta Palaeontologica Polonica 58 (2), 2013: 351-355 doi: http://dx.doi.org/10.4202/app.2011.0150
}

Clusters of gastropod egg capsules, inferred to be of neritoids and attached to the inner shell wall of the ultimate whorl of a large volutid gastropod, are here recorded from the upper Nekum Member (Maastricht Formation; late Maastrichtian) of the ENCI-Heidelberg Cement Group quarry, St Pietersberg (Maastricht, southeast Netherlands). Because the aragonitic shell of the volutid has dissolved, the outlines of the egg capsules are now revealed on the steinkern of indurated biocalcarenite, having been subsequently overgrown by cheilostome bryozoan colonies and preserved as mould bioimmurations. This represents the first example of gastropod eggs preserved through bioimmuration, as well as the first record of gastropod eggs from the Cretaceous.

Michał Zatoń [mzaton@wnoz.us.edu.pl](corresponding author), Uniwersytet Śląski, Wydział Nauk o Ziemi, ul. Będzińska 60, PL-41-200 Sosnowiec, Poland; Paul D. Taylor [p.taylor@nhm.ac.uk], The Natural History Museum, Department of Palaeontology, Cromwell Road, London SW7 5BD, United Kingdom; John W.M. Jagt [john.jagt@maastricht.nl], Natuurhistorisch Museum Maastricht, de Bosquetplein 6-7, NL-6211 KJ Maastricht, the Netherlands.

This is an open-access article distributed under the terms of the Creative Commons Attribution License (for details please see creativecommons.org), which permits unrestricted use, distribution, and reproduction in any medium, provided the original author and source are credited. 